\title{
Novitates ZOOLOGICAE.
}

Vol. XII.

SEPTEMBER, 1905.

No. 2 .

\section{FURTHER CONTRIBUTIONS TO OUR KNOWLEDGE OF THE ORNIS OF THE SOLOMON ISLANDS.}

BY THE HON. WALTER ROTHSCHILD, Ph.D., AND Dr. ERNST HARTERT.

\author{
(Plate X.)
}

TN Nov. Zool. viii., 1901, pp. 179-89, 373-82, we have discussed the birds of the islands Kulambangra, Florida, and Guadalcanar; in vol. ix., 1902, pp. 581-94, we wrote about those from Isabel (Bugotu) and Treasury Island. The indefatigable collector Mr. Albert S. Meek has recently returned to the Solomon Archipelago, and has succeeded in making very valuable collections on Rendova, Gizo, New Georgia, Choiseul, and Bougainville, notwithstanding the bad climate and the notorious ferocity of the natives. The birds collected by Mr. Meek are of course of the highest interest, becanse our knowledge of the birds of Rendova and New Georgia was imperfect, and of those of Gizo, Choiseul, and Bougainville we knew heretofore nothing. It is true that Dr. Julius von Madarász, in Természetrajzi Füzetek xxv., 1902, pp. 350-51, described nine species as coming from Bougainville, but we have shown (Annales Mus. Nat. Hungar. i., 1903, pp. 447-50) that these did not come from Bougainville, but from German New Guinea. Needless to say that the large collection received from Mr. Meek fully bears out our conclusions, l.c.

The number of remarkable new species in the collection from the northern islands is surprisingly small. This is, however, explained by the fact that the ornis of Bougainville, Choiseul, and Isabel is, on the whole, the same. Moreover, Mr. Meek was of course not able to penetrate far into the interior, but had to restrict his collecting to the coastal portions of the islands. There can be no doubt whatever that the mountains in the interior of these islands, and especially those of Bougainville, are still inhabited by unknown, differentiated forms, although Meek's collections give a splendid idea of the zoogeographical relations of these islands.

A few startling, wonderful discoveries were also made: the remarkable new pigeon Microgoura meeki, the gandy Halcyon bougaincillei, and the sombre Corcus meeki, while in other groups highly interesting new subspecies were discovered, as, for example, in the genera Astur, Pitta, and Graucalus.

The collection shows the following interesting facts :-

1. The ornis of the islands of the northern chain-ie. the three islands of Bougainville, Choiseul and Isabel-is generally alike; only in comparatively few cases representative subspecies are found on the various islands of the northern chain. 
2. The ornis of these northern islands differs remarkably from that of the New Georgia, or central group, as we may call it.

3. The fauna of the islands of this central group-i.e. the islands of Gizo, or Guizo, Kulambangra, Rendova, and New Georgia-is generally the same ; only in a very few cases representative forms are found on these islands, while nearly always (except when the same forms are spread over the whole, or nearly the whole, archipelago) the forms from the northern chain, as well as those from Guadalcanar, differ from those of the central group.

4. We can thus distinguish the following geographical groups of islands in the Solomon Archipelago :

(a) The northern chain (Bougainville, Choiseul, Isabel).

(b) The central group (New Georgia, Kulambangra, Gizo, Rendova).

(c) The Guadalcanar group (Guadalcanar and Florida).

(d) The sonthern group (San Christoval, Ugi).

The large islands of Malaita and Rennel, as well as many smaller, less important islets, remain unknown, but we hope that collections from some of them will reach us before long, as well as from San Cristoval, which has many very distinct birds, not yet represented in the Tring Museum.

Mr. Meek is to be congratulated on having achieved a visit to Choisenl and Bougainville, which are probably among the most difficult islands to visit, on account of the want of communication and the hostility of the natives, and we hope that he will long continue his successful explorations of the islands of the Papuan Region.

\section{Megapodius duperreyii eremita Hartl.}

[Megapodius duperreyii Lesson \& Garn., Bull. Sci. Nat. viii. p. 113 (1826-Dorey).]

Megapodius eremita Hartl., P. Z. S., 1867, p. 830 (Echiquier Is.).

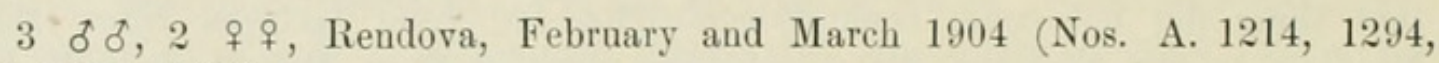
$1333,1345,1389)$.

"Iris hazel (brown) ; feet black (greenish slate) ; bill dull yellow (yellowish)."

1 pull., Choiseul, 8. xii. 1903 (No. A. 892).

1 ठ, 3 \& + , 1 pull., Bongainville, April and May 1904 (Nos. A. 1519, 1533, $1656,1715,1755)$.

An egg from Choiseul is of a vinaceous flesh-colour, and measures $81.5 \times$ $50.5 \mathrm{~mm}$.

\section{Ptilinopus superba (Temm.).}

Columba superba Temminck, in Knip, Les Pigeons, p. 75, pl. 33 (1811-

2 ठठ $\delta$, New Georgia, March, 1904 (Nos. A. 1396, 1432).

2 ठ ठ

$1 \delta, 1$ \&, Choisenl, December 1903 (Nos. A. 1002, 1031).

4 ठ์ ठ์, 2 q $q$, Bongainville, April 1904 (Nos. A. 1491, 1529, 1590, 1626, 1662, 1672).

"Iris yellow (pale yellowish); feet purplish red; bill, $\delta$ green-slate (slate + )."

An egg was taken on Choiseul on January 11th, 1904. It is very smooth, though without gloss, of a milky white, and measures $32 \times 21.6 \mathrm{~mm}$. 


\section{Ptilinopus solomonensis solomonensis Gray.}

Ptilonopus solomonensis Gray, Ann. \& Mag. Nat. Hist. (4) v. p. 328 (1870-q "Solomon Islands").

1 ठ, New Georgia, 9. iii. 1904 (No. A. 1416).

"Iris yellow ; feet purplish red ; bill green-slate."

2 \& + , Rendova, February 1904 (Nos. A. 1187, 1265).

\section{Ptilinopus lewisii lewisii Rams.}

Ptilopus lewisii Ramsay, Proc. Linn. Soc. N. S. Wales vi. p. 724 (1881-ex op. cit. iv., 1879, pp. 73, 74: "Lango ; Gaudaleanar").

1 \&, Rendova, 5. ii. 1904 (No. A. 1186).

1 ठ, 3 \& \&, Gizo, November 1903 (Nos. A. 713, 736, 811, 851).

2 ठో ठే, 1 \&, Choiseul, December 1903 (Nos. A. 951, 1003, 1059).

1 o , Bougainville, 22. iv. 1904 (No. A. 1623).

"Iris yellow (dull yellow, reddish yellow); feet dark purple (purplish red); bill bright straw-yellow (greenish yellow)."

\section{Carpophaga rufigula Salvad.}

Carpophaga rufigula Salvadori, Atti R. Acc. Sc. Torino xiii. p. 536 (1878-San Christoval Solomon Is.).

2 ठ̊ \& Rendova, February 1904 (Nos. A. 1323, 133\%).

2 ठठ ठै, Gizo, October 1903 (Nos. A. 624, 625).

1 ơ, Bougainville, 7. v. 1904 (No. A. 1754).

"Iris dark red; feet purplish red (bright purple) ; bill dark slate-colour."

We have not been able to compare examples from San Christoval!

\section{Carpophaga pristinaria Bp.}

Carpophaga pristinaria Bonaparte, Consp. Av. ii, p. 36 (1854-" St. George Island ").

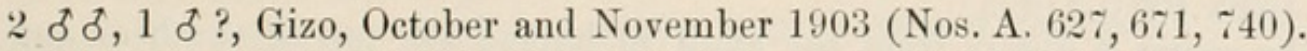

1 \&, Choisenl, 18. xii. 1903 (No. A. 971).

$3 \delta \delta, 2 q q$, Bongainville, April and May 1904 (Nos. A. 1554, 1665, 1674, $1728,1733)$.

Two eggs, belonging to the of No. A. 971, were taken on Choiseul, 18. xii. 1903. They are white, almost without any gloss, and measure $47 \times 33 \cdot 2$ and $52 \times 33 \mathrm{~mm}$.

\section{Columba philippanae (Rams.)??}

Ianthoenus philippanae (sic!) Ramsay, Proc. Linn. Soc. N. S. Wales, vi. p. 721 (1881-Ugi, Solomon Is.).

1 juv. ("ठ ?") Choiseul, 8. xii. 1903 (No. A. 891).

"Iris and feet dirty yellow, bill slaty."

$1 \delta$ fere ad., Bongainville, 10. iv. 1904 (No. A. 1490).

"Iris yellow and red ; feet pale yellow ; bill slate and dull red."

As there are, to our knowledge, no specimens of $C$. philippanae, nor of the closely allied $C$. pallidiceps from Duke of York Island, in Europe, we are not able to say if our specimens belong to either of them. We are inclined to think that they belong to a third subspecies, but may be philippanae. The crowns are 
moulting into french grey, the throats are whitish grey. The feathers of the body-plnmage above are slaty or brownish black with wide opalescent greeuish and reddish tips, those of the under surface slate-grey, widely tipped with opalescent glossy green on the breast, more narrowly and less distinctly on the abdomen.

\section{Macropygia rufa rufocastanea Rams.}

Macropygia rufocastanea Ramsay, Proc. Limn. Soc. N. S. Wales iv. p. 314 (1879-Lango, Guadalcanar).

1 \&, Rendova, 24. ii. 1904 (No. A. 1364).

2 ठे ठ, 2 क +. New Georgia, 7, 8, 10. iii. 1904 (Nos. A. 1397, 1404, 1421, 1431).

1 \&, Choiseul, 22. xii. 1903 (No. A. 1008).

1 ठे, Bougainville, 12. v. 1904 (No. A. 1\% \%).

"Iris yellowish red (crimson); feet red ; bill black."

\section{Coryphoenas crassirostris (Gould).}

Turacoena crassirostris Gould, P. Z. S. 1856, p. 136 (Guadalcanar).

1 q ad., 1 q juv., Rendeva, 26. ii. 1904 (Nos. A. 1378, 1379).

"Iris yellow (dull yellow in the young); feet pnrplish red (black in the young); bill brick-red in the adult."

\section{Chalcophaps stephani mortoni Rams.}

Chalcophaps mortoni Ramsay, Proc. Linn. Soc. N. S. Wales vi. p. 725 (1881-Ugi, Solomon Is.).

$2 \delta$ ठ․, Reudova, 17, 28. ii. 1904 (Nos. A. 1324, 1384).

2 \& , New Georgia, 9. iii. 1904 (Nos. A. 1409, 1414).

4 ठे ठे, Gizo, 28. x. ; 1, 2, 10. xi. 1903 (Nos. A. 663, 711, 717, 873).

1 ठ, 1 \&, 1 \& juv., Choiseul, 7, 28, 29. xii. 1903 (Nos. A. 887, 1060, 1064).

5 ơ of, 1 \& , Bongainville, 11, 15, 20, 21. iv. ; 5. v. 1904 (Nos. A. 1493, 1539, $1541,1595,1607,1735)$.

The young $q$ differs from the adult in having the top of the head and hindneck chestunt without any plum-coloured tinge and without grey on the forehead.

"Iris brown ; feet bright red ; bill yellow."

11. Phlegoenas beccarii intermedia subspec. nov.

Subspeciei Phl. beccarii johannae dictae simillima, sed abdomine pulliore, purpurascentiore, jugulo grisescentiore.

This new form is nearest to Phl. bece. johannae, but differs by the less whitish foreneck and chest, which are more greyish, and by the colour of the abdomen, which is darker and more purplish bronze. The bronze colour of the upperside has a more greenish, less reddish tinge.

Type: $\delta$ ad., Bougainville, 17. iv. 1904, No. A. 1569, A. S. Meek coll.

Mr. Meek sent, in addition to the type, the following two specimens :

o ad., New Georgia, 14. iii. 1904 (No. A. 1461).

o ad., Gizo, 14. ii. 1903 (No. A. 850 ).

These two specimens from the New Georgia group are more reddish bronze above, and the abdomen appears to be slightly darker. It is quite possible that 
we have here a further subspecies, but until more specimens, especially from Bongainville, can be examined, this question must remain in abeyance.

"Iris brown (dark brown) ; feet red (dark red, bright purplish red); bill black."

There is no doubt that beccarii, johannae, solomonensis (=granti), are subspecies of one species. Phl. beccarii solomonensis Grant 1888 (=granti, Salvadori 1893), differs from intermedia in being considerably larger and much more purplish on the back, while the grey colour of the throat is darker. We do not reject solomonensis Grant on account of there being already a salomonis Rams., the two names being obvionsly different. We also think it very likely that the specimens called beccarii from British New Gninea will eventually be separable, as the only Arfak skin we have seen is less greenish above.

\section{Microgoura meeki Rothsch.}

Microgoura meeki Rothschild, Bull. B. O. C. xiv. p. 78 (May 1904); (Nov. Zool. 1904, Pl. XXI.).

$\delta$ ad. Bill chalky blue, tip black, lower mandible reddish. Short velvety feathers on chin ; lores, sides of mouth and line over the forehead black. Top of head and scanty feathers on sides of same pale greyish blue; crest-feathers pale bluish grey, rather nniform, but not spotty, as in the plate. Chest and mantle blnish grey. Lower back and rump greyish brown; upper tail-coverts dark brown with purplish and greenish reflexions; primaries drab-brown, inner webs with a greyish tinge; secondaries dnll cinnamon, inner webs more or less greyish brown. Wing-coverts greyish brown. Rectrices dark purple. Breast and abdomen bright rufous-cinnamon. Under tail-coverts glossy brownish black, with cinnamon edges. Under wing-coverts bright cinnamon. Wing, of 195 to 197 , $q$ about 180 to $190 \mathrm{~mm}$.; tail 100 to 105 ; bill, from base of cere, 34 to 35 ; metatarsus 60 ; middle toe with claw 40 , hind toe with claw about $13 \mathrm{~mm}$.

This remarkable new pigeon agrees with none of the known genera, so that a new one had to be created for it. The cere is naked to the forehead, the soft portion from the end of the hard rhamphotheca to the feathering on the forehead being nearly $25 \mathrm{~mm}$. long, and about $13 \mathrm{~mm}$. wide at the base of the forehead. A large flat crest, consisting of feathers with segregated barbs, rising from the occiput. Remiges very hard and stiff. Tail short and ronnded. Feet and legs bare to above the heel-joint, covered in front with scutes, which, however, become indistinct on the upper third.

Mr. Meek sent seven specimens, of which six are in the Tring Mnsenm.

3 ठठ ठै, 3 q $q$, Choisenl, January 1904 (Nos. A. 1091, 1094, 1108, 1109, 1110, 1126).

An egg was taken on January 10th. It is of a rich cream-colour, and measures $43 \times 31.3 \mathrm{~mm}$.

\section{Caloenas nicobarica (L.).}

Columba nicobarica Linnaeus, Syst. Nat. ed. x. p. 164 (1758: "Habitat in insula Nicombar prope Pegu indicum ").

$1 \delta, 2 q q$, Rendova, February 1904 (Nos. A. 1181, 1271, 1365).

1 ठ, 2 q , Gizo, October 1903 (Nos. A. 660, 679, 680).

1 ठ, 1 f, Choiseul, January 1904 (Nos. A. 1122, 1150).

$1 \delta, 1$ \&, Bongainville, April and May 1904 (Nos. A. 1660, 1\%9). 


\section{Eulabeornis woodfordi (Grant) (?)}

Rallina voodfordi Grant, Amm. \& .IFag. Nat. Hist. (6) iv. p. 320 (1889: Guadalcanar) ; Cat. B. Brit. M/us. xxiii. p. 50, pl. vii.

ơ + , Bongainville, 30. iv., 5. v. 1904 (Nos. A. 1700, 1734).

"Iris dark red ; feet, o slate, + pale ashy blne ; bill slate."

Of Eulabeornis woodfordi only the type in the British Musenm appears to be known. Onr birds, which are apparently adnlt, agree fairly well with the type, thongh not in all details. The bill is in the skins whitish, yellowish and slaty towards the base. The description as "slate" on the labels is apparently made "cum grano salis." The type of E. woodfordi has a blackish bill. The under tail-coverts have white spots. Wing, o 155, $q 148$; bill, $\delta$ (from end of feathering) 43 ; metatarsus abont $60 \mathrm{~mm}$.

We donbt that the type is "immature."

\section{Porphyrio smaragdinus Temm.}

Porphyrio smaragdimus Temminck, Pl. Cal. v. Taf. 421 (1826 : Banda, Java).

ơ ad. Choisenl, 11. xii. 1903 (No. A. 917).

\section{Nycticorax mandibularis Grant.}

Nycticorax mandibularis Grant, P. Z. S. 1888. p. 203 (Guadalcanar).

1 ơ ad., 1 \& ad., 1 of juv., Rendova, February 1904 (Nos. A. 1197, 1288, $130 \%)$.

"Bill black, lower mandible greenish yellow with blackish tip."

Though a distinct form, $N$. mandibularis is probably the representative subspecies of $N$. caledonicus on the Solomon Islands.

\section{Anas superciliosa pelewensis Hartl. \& Finsch.}

[Anas superciliosa Gmelin, Syst. Nat. i. 2. p. 537 (1788: ex Latham-" hab. in Nova Seelandia").] A nas superciliosa var, pelerensis Hartl. \& Finsch, P. Z. S. 1872. p. 108 (Pelew Islands).

There is no doubt that the specimens from the Pelew Islands, Samoa, Fiji, and most conspicuonsly those from the Solomon Islands, are very much smaller (wings 1 to $2 \frac{1}{2}$ inches shorter, bill smaller, etc.) than those from Anstralia and New Zealand. To emphasize this fact we use the above nomenclature. A. s. pelewensis is the only available name for the small race. Anas leucophrys Forster (1844) refers to the New Zealand form, Anas mülleri Bonaparte (1856) is a nomen nudum : There is, nerertheless, one difficulty : the specimens from the Kangean Islands, near Java, and those from Java, are also as small, or nearly as small as those from the Sonth Sea Islands, while those from Savu, Timor and Sumba are of the big race. The question, therefore, arises whether there are two small races, one in the Pacific and another on the Sunda Islands, or whether all these form one small race. Against the first possibility stands the fact, that all those small birds are - at least so it seems to ns, after having examined a few examples only !-apparently alike, and with the second possibility the distribution does not seem to agree very well. At present we can, therefore, only emphasize the fact that there is, besides the larger Anas superciliosa superciliosa from New Zealand and Australia, a small race in the Pacific, which we call A. superciliosa pelewensis. 
Mr. Meek sent the following specimens :

3 ठठ ठ, 1 ․ Rendova, February 1904 (Nos. A. 1254, 1255, 1269, 1344).

1 o, Choiseul, 10. xii. 1903 (No. A. 97\%).

2 ठิ ठै, Bougainville, May 1904 (Nos. A. 1767, 17\%1).

"Iris chocolate-brown ; fect dull tan-colour (light tan) ; bill black (slate)."

\section{Astur albogularis (Gray).}

Accipiter albogularis Gray, Am. Nat. Hist. (4) v. p. 327 (1870: San Christoval).

Astur holomelas Sharpe, P. Z. S. 1888, p. 182 (Aola, Guadalcanar).

Astur woodfordi Sharpe, P. Z. S. 1888, p. 183 (Guadalcanar).

Astur versicolor Ramsay, Proc. Linn. Soc. N. S. Wales, vi. p. 718 (1882: Ugi, near San Christoval).

(Cf. Nor. Zool. 1901. pp. 379, 380.)

Astur albogularis and woodfordi were separated, because the latter has a vinous collar on the hind-neck. We have found that specimens with this collar occur side by side with others withont any indication of it, and others again, in which it is more or less indicated and developed. This clearly shows that it is no specific character. When A. versicolor was described, it was suggested that it might be a melanistic aberration of albogularis, and when holomelas was named the suggestion was made that it might be a melanism of woodfordi. We (Nov. Zool. 1901, p. 380) also suggested the probability of the black birds being melanistic examples of $A$. albogularis (= woodfordi). Now we cannot any longer doubt that this is the case. We have an adult male from Choisenl (No. A. 1105) which has the throat and chest slaty black, towards the abdomen mixed with greyish and white, while the abdomen, thighs and nnder tail-coverts are pnre white. Another male is white below with one small blackish spot on the chest and a vinous-rufons collar above, which encroaches on the underside, a third white below withont a collar on the upper surface.

It is thus evident that we have a black-and-white species which varies very much, and is spread over most of the Solomon Islands-in striking opposition to the grey-and-rnfous species, which is rather constant in any given locality, but varies locally, thus being separable into a number of subspecies.

Great as the variation is among the adult birds, it is equally striking in the young birds. A male from Rendova has the npperside blackish brown and rufous, the central rectrices slaty grey, gradually merging into pale cinnamon with a grey wash on the outer rectrices, all being barred with blackish bands. Underside rusty buff, each feather with a longitudinal lanceolate spot in the middle, but those of the throat and under tail-coverts uniform, those of the flanks with wide dark brown bars. A female from Choisenl is above much more dark cinnamon, with less black, the middle rectrices more tinged with cinnamon, the underside bright cinnamon with brown stripes on the throat, and brown, varionsly shaped cross-markings on the rest of the underside. Another female from Choisenl has the chest and breast narrowly barred with brown, on a cream-coloured ground, while a male from the same island has much wider and deeper brown bars. The heads and hind-necks of these birds are white with broad black tips to the feathers.

$1 \delta$ juv., Rendova, 24. ii. 1904 (No. A. 1372).

$1 \delta$ ad., New Georgia, 11. iii. 1904 (No. A. 1440).

3 o $\delta$ ad., 2 i \& juv., 1 o juv., Choisenl, December 1903, January 1904 (Nos. A. 913, 980, 1040, 1105, 1125, 1162).

"Adults : Iris cadmium-yellow (dirty yellow in a bird monlting from the 
juvenile plumage, but monlt almost completed) (dark brown in No. 1105-(?)-) (golden Jellow); $\delta$ juv. lemon-yellow ; $q$ juv. yellow ; feet in adults (lemon) yellow, in young ones also yellow; bill black (slate, bluish slate); in young blue-slate with black tip."

The young female, No. 3248 Meek coll., described Nov. Zool. 1902, p. 591, of which we already suggested that it might not belong to A. ruforchistaceus, is also a young $A$. albogularis.

\section{Astur etorques rubianae subsp. nov.}

Astur supra cano-schistaceus, subtus saturate rufo-cinnamomeus.-Subspeciei A. e, rufoschistaceus dictae similis, sed minor, coloribus saturatioribus, pullioribus. of al. $195-200$, $q$ al. 206$214 \mathrm{~mm}$.

Hab. Rubiana (New Georgia); Gizo, Rendova (Type: + ad. Gizo, 27. xi. 1903, No. A. 652. A. S. Meek coll.)

2 ơ ad., 2 \& ad., Rendova, February 1904 (Nos. A.1199, 1200, 1268, 1341).

$1 \delta$ fere ad., 1 \& juv., New Georgia, March 1904 (Nos. A. 1410, 1454).

1 i ad., Gizo, 27. xi. 1903 (No. A. 652).

"Iris reddish brown (bright chocolate); feet cadmium (bright yellow); bill black, cere yellow."

\section{Astur etorques rufoschistaceus R. \& H.}

Astur rufoschistaceus Rothsch. \& Hart., Nov. Zool. 1902, p. 590 (Isabel).

$2 \delta$ ad., $2 \uparrow$ ad., 1 ठ juv., 1 q juv., Choisenl, December 1903 (Nos. A. 885, 964, $9 \% 8,1032,1082,1083)$.

"Ad. : Iris dark brown ; feet cadminm ; bill black."

\section{Astur etorques bougainvillei subsp. nov.}

Astur subspeciei A. e. rufoschistaceus dictae persimilis, sed colore cinereo dorsi, colli, capitisque pallidiore, necnon statura minore, haud difficile distinguendus. Al. ठ 194-199 mm.

Hab. Bongainville Island. (Type, No. A. 1556. A. S. Meek coll.)

5 o o ad., Bongainville Island, April 1904 (Nos. 155.5, 1611, 1619, 1659, 1689).

"Iris brown ; feet cadmium ; bill black."

\section{The rufous-and-grey Astur-group.}

In Nov. Zool. 1901, p. 380, we united Astur pulchellus Rams, and A. shebae Sharpe, and in Noo. Zool. 1902, p. 590, we described A. rufoschistaceus from Isabel as a new subspecies. We were right in considering A. shebae to be a synouym of $A$. pulchellus, but not when we concluded from this that the birds from New Georgia were identical with those from Guadalcanar.

Dr. Ramsay most clearly described a bird with pale thighs, and Dr. Sharpe, therefore, was wrong in taking the form with dark thighs from the central group as pulcliellus, and separating from it the Guadaleanar bird with pale thighs. The difficulty is, that Dr. Ramsay gave as the original locality of his pulchellus "Cape Pitt," and later on "Cape Pitt, Guadalcanar." As "Cape Pitt" we find marked on all maps the sonthernmost point of New Georgia. There must therefore have been an error in the original statement, either that a place on Guadalcanar was called Cape Pitt, or that there was some other misunderstanding, because it is perfectly clear that Dr. Ramsay described the pale-legged form from Guadalcanar, which 
is represented on the New Georgia gronp (New Georgia or Rubiana, Kulambangra, Guizo and Rendova) by one with dark thighs. A careful comparison of the material from the Solomon Islands brings us to the conclusion that the following forms are distinguishable:

1. Astur etorques etorques Salvad., 18:8-New Guinea and some of the adjacent islands. Colour of upper throat greyish, generally with traces of bars, and more or less merging into that of the breast and abdomen. Many apparently adult specimens have partly barred nudersides. Probably some of the forms found on the small islands are again separable.

2. Astur etorques dampieri Gurney, 1882-Bismarck Archipelago. Differs apparently in being paler and in having lighter nnder wing-coverts. We have only seen a few specimens.

3. Astur etorques bougainvillei subsp. nov.-Bougainville Island, northern Solomon Islands, and Shortland gronp. This and all the other forms from the Solomon Islands have the throat and chin grey, sharply divided from the rufonscinnamon underside. Upper surface pale grey, lighter than in A. e. rufoschistaceus. Wing, ठ, 194-199 $\mathrm{mm}$.

4. Astur etorques rufoschistaceus Rothsch. \& Hart., 1902-Isabel and Choisenl Islands, northern Solomon Islands. Very similar to A. e. bougainvillei, bnt the upper surface a little darker; wings longer. of, wing $212-226 \mathrm{~mm}$. , + , wing $240-251 \mathrm{~mm}$.

5. Astur etorques pulchellus Rams. 188I.-Gnadalcanar and Florida Islands, Solomon group. At once distinguishable by its light thighs and under wingcoverts.

6. Astur etorques rubianae subsp. nov.-Rubiana (New Georgia) gronp : New Georgia, Rendova, Gizo. Darker and smaller than A. e. rufoschistaceus, especially the under surface of a deeper, nearly chestnut colour. Wing, o 195-200; $q$ 211-214 mm.

\section{Baza subcristata gurneyi Rams.}

Basa gurneyi Ramsay, Journ. Linn. Soc, Zool, xvi. p. 130 (1881 : Solomon Islands). (Cf. Nov, Żol. 1901, p. 379.)

2 ठㅇ, 4 \& , Rendova, February 1904 (Nos. A. 1236, 1238, 1250, 1252, 1343, 1362).

2 ठठ ठै, Gizo, November 1903 (Nos. A. 757, 821).

$2 \delta$ ठ , 1 \& , Choisenl, Jannary 1904 (Nos. A. 1086, 1151, 1152).

3 \& \&, Bongainville, April, May 1904 (Nos. A. 1633, 1749, 1750).

"Iris chrome-yellow (bright yellow); feet pale slate (horn-colour); bill slate and black (blue-slate and black)."

\section{Falco severus Horsf.}

Faleo severus Horsfield, Trans. Zool. Soc, xiii. p. 135 (1821 : Java).

1 “q," Gizo, Solomon Islands, 12. xi. 1903 (No. A. 830).

"Iris dark brown; feet lemon-yellow ; bill black, slaty at base."

Messrs. Meyer \& Wiglesworth have separated three races of this species (B. of Celebes, i. p. 84).

1. Falco severus indicus from India. Said to be paler above, with a brownish slaty tail, and with tail and wings barred below on the inner webs. 
2. Falco secerus secerus from the Malayan Archipelago. Intermediate between $F . s$. indicus and F.s. papuanus.

3. Falco severus papuanus from New Guinea. Said to be darker above and below, with darker tail and entirely nnbanded wings and tail.

The examination of our material clearly shows that the supposed "papuanus" is not separable from typical severus. The anthors of "papuanus" should have hesitated in naming it from their scanty material. They were evidently not aware that the bars on the nnderside of the wings and tail disappear in old birds, while they are most pronounced in young ones.

With regard to the Indian subspecies we cannot speak confidently, but the few specimens which we were able to compare seem to confirm the theory of Messrs. Meyer \& Wiglesworth that it is a lighter form. In that case we would have to recognise one form which is spread all over the archipelago, another inhabiting continental India and Ceylon.

\section{Pseudoptynx solomonensis Hart.}

Psendoptynx solomonensis Hartert, Bull. B. O. C. Nov. 1901, p. 25 (Isabel).

$2 \delta$ ठै, Choisenl, January 1904 (Nos. A. 1123, 1142). "Iris chrome-yellow ; feet ashy grey ; bill blackish (slate), tip whitish."

\section{Ninox jacquinoti (Bp.).}

Athrne jacquinoti Bonaparte, Consp. Av. i. p. 42 (1850; ex Hombron \& Jacqu. ; hab. "Oceania." Typ. loc., "San Jorge, Iles Salomon," vide Jacqu. \& Pucheran). (Cf. Nov. Zool. 1902, p. 592.)

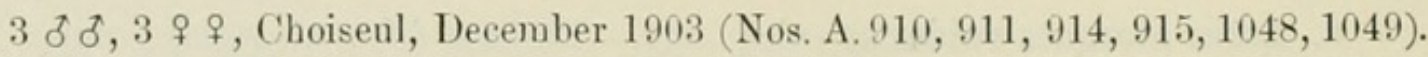

2 ठठ $\delta, 2$ ㅇ, Bongainville, April, May 1904 (Nos. A. 1505, 1506, 1507, 17\%2).

\section{Eos cardinalis (Gray).}

Lorius cardinalis G. R. Gray, Gen. B., App. p. 20 (1849 : ex Hombr \& Jacq., Solomon Islands).

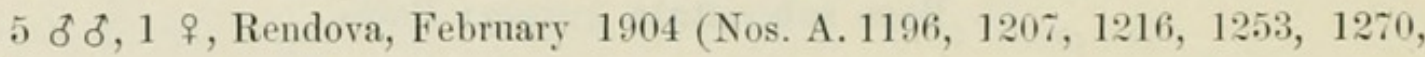
1351).

2 ठ क \&, Gizo, October 1903 (Nos. A. 620, 626).

3 of ठ, 1 क , Choisenl, December 1903 (Nos. A. 930, 940, 953, 1010).

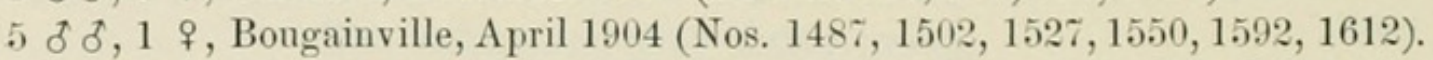

A young bird from Choisenl resembles the old ones, but the red is duller, the bill for the most part blackish. This beautiful Parrakeet seems to occur on the Solomon Islands only, but there it is apparently common on all the larger and median islands, at least on those from which we have received collections.

\section{Trichoglossus haematodus massena Bp.}

Trichoglossus massena Bonaparte, Rev. \& Mag. de Zool. 1854, p. 157 ("Insulae Polynesiae"). (Cf. Nov. Zool. 1901, pp. 70, 186.)

$2 \delta$ ơ, Rendova, February 1904 (Nos. A. 1287, 1371).

3 ठో ठ, 2 ㅇ , New Georgia, March 1904 (Nos. A. 1420, 1426, 1427, 1435, 1436).

4 ठठ $\delta, 2$ \&, Gizo, November 1903 (Nos. A. 776, 777, 789, 790, 791, 796).

2 ठे ठै, 2 \& $q$, Choiseul, December 1903 (Nos. A. 881, 990, 994, 999).

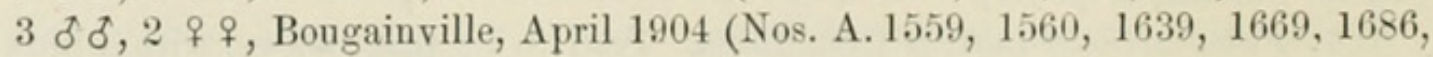
1688). 
The abdomen is generally green, the upper portion with red, the lower ones with yellow bases to the feathers; but in some there is a rather distinct blue-black line between the red breast and the green abdomen, while a male (No. A. 990) from New Georgia has a large blne-black patch covering the npper part of the abdomen. In the specimens from the Solomon Islands the green nnchal band is generally, but not always, interrupted in the middle, while in those from New Guinea and the Lonisiades it is more regularly complete and generally more yellowish. There is, however, no constancy in these characters.

\section{Charmosynopsis placentis pallidior subsp. nov.}

Similis subspeciei $C h$. placentis subplacens dictae, sed colore supra pallidiore, macula auriculari dilutiore dietinguenda.

$4 \delta$ o, 2 $q$, Bongainville, end of April and first half of May 1904 (Nos. A. 1699, $1714,1717,1721,1757,1758)$.

"Iris, o red, of dull yellowish red ; feet dull red ; bill rose-madder (red)."

While the specimens from Bongainville, the only island of the Solomons whence we know of this bird, agree with those from New Britain, New Ireland, and New Hanover, those from the mountains of British New Guinea are darker green above, and have the auricular patch much lighter. We have thus three subspecies:

1. Ch. placentis placentis (Temm.). Original locality Utanata, Dutch New Guinea. With a large blue pateh on the uropygium !

2. Ch. placentis subplacens (Scl.). Original locality, mountains near Naiabui in S.E. New Guinea. Withont a blue patch on the uropyginm, colonr of npper surface darker green, blue anricular patch darker blue.

3. Ch. placentis pallidior Rothsch. \& Hart. Type: ठ ad. Bongainville, 8. v. 1904, No. A. 1757, Meek coll. Withont a blue patch on the uropyginm, colour of upper surface paler green, auricular patch lighter blue; wings generally slightly shorter.

Specimens from German New Guinea, Milne Bay, and Woodlark Island seem to be somewhat intermediate between subplacens and pallidior, but we have only examined a few.

We see no reason for distingnishing between the genera Charmosynopsis and " Hypocharmosyna."

\section{Charmosynopsis margarethae (Tristr.).}

Charmosyna maryarethae Tristram, Ibis 1879, p. 442, pl. xii. (Ugi and San Cristoval, Solomon Islands). (Cf. Nov. Zool. 1901, pp. 187, 378.)

1 f immat., Bongainville, i. v. 1904 (No. A. 1708).

"Iris dull red ; feet tan-colour ; bill dull red."

30. Eclectus pectoralis salomonensis Rothsch. \& Hart.

Eclectus pectoralis solomonensis Rothsch. \& Hart, Nor. Zool. 1901, p. 82 (various Solomon Islands. type from Fauro).

1 ơ, Rendova, February 1904 (No. A. 1375).

1 \&, New Georgia, March 1904 (No. A. 141\%).

2 o ठ ', Gizo, October, November 1903 (Nos. A. 654, 7\%0).

$4 \delta \delta, 2$ $\subsetneq$, Bongainville, April, May 1904 (Nos. 1515, 1597, 1666, 1670, $1731,1759)$. 
31. Geoffroyus heteroclitus (Hombr. \& Jacq.).

Pxittacus Geoffroyi heteroclitus Hombr. \& Jacq., Amn Soc. Nat. L. ser. xvi. p. 319 (1841: "Saint Jorge et Ysabel, Iles Salomon ").

2 ठิ ठ, 1 ㅇ, Rendora, February 1904 (Nos. A. 1198, 1223, 1228).

3 ठे ठे, New Georgia, March 1904 (Nos. A. 1401, 1405, 1413).

3 ठेठ丿, 1 q, Gizo, October, November 1903 (Nos. A. 619, 651, శ67, 838).

2 ठे ठै, 2 $\uparrow$, Choisenl, December 1903, January 1904 (Nos. A. 925, 1018, 1019, 1092).

3 \& ad., 1 \&, 1 ठ juv., Bongainville, April and May 1904 (Nos. A. 1516, 1613, 1\%07, 1\%2\%, 1\%41).

"Iris ivory white (dull whitish in young); feet greenish slate; bill black; upper mandible more or less yellow."

\section{Nasiterna aolae tristrami Rothsch. \& Hart.}

Nasiterna tristrami Rothsch. \& Hart., Nov. Zool. 1902, p. 589 (Kulambangra).

$4 \delta \delta, 4$ § , Gizo, October and November 1903 (Nos. A. 611, 728, 804, 824, $847,848,852,85 \pi)$.

$1 \delta, 2 q q$, New Georgia, March 1904 (Nos. A. 1399, 1400, 1406).

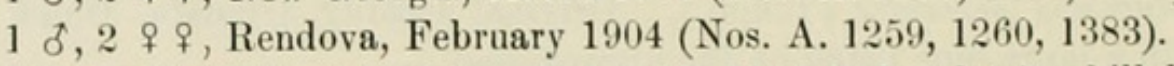
(slate)."

"Iris red (yellowish red); feet ashy blue (pale slate); bill blackish slate

We know this form now from Knlambangra, Rendova, New Georgia, and Gizo.

\section{Nasiterna aolae nanina Tristr.}

Nasiterna nanina Tristram, Ibis 1891, p. 608 (Isabel). (Cf. Nov. Zool. 1901, p. 188, 1902, p. 589.)

5 ठ̊ठ์, 2 q , Choisenl, December 1903 (Nos. A. 865, 895, 1000, 1009, 1015, $1024,1025)$.

3 o ठ o, Bongainville, April 1904 (Nos. A 1478, 167\%, 1756).

"Iris red (yellowish red, dnll yellow); feet ashy blue; bill dark slate (black).

We know this form now from Isabel, Choisenl, and Bongainville.

\section{Cacatua ducorpsii Jacq. \& Puch.}

Cacatua Ducorpsii Jacq. \& Puch. Voy. Pôle Sud, Zool. iii p. 108 (1852 : “ Iles Salomon ”).

2 \& , Rendova, February 1904 (Nos. A. 1306, 1352).

1 ช̊, New Georgia, March 1904 (No. A. 1398).

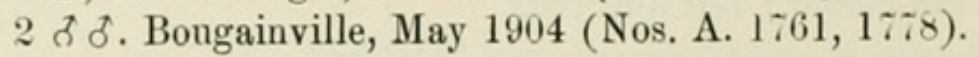

\section{Eurystomus solomonensis Sharpe.}

Eurystomus solomonensis Sharpe, P.Z.S. 1890, p. 552 (Ugi).

$3 \delta \delta, 3 q q$, New Georgia, March 1904 (Nos. A. 1410, 1425, 1433, 1445, 1446, 1447).

1 б, Bongainville, May 1904 (No. A. 1729).

The younger individuals have the upper mandible dark brown, but the adult ones quite red, 
36. Alcedo ispida salomonensis subsp. nov.

The central group of the Solomon Islands, Gizo, Rendova, and presumably also New Georgia, are inhabited by a beautiful, very blue and brightly coloured race of Kingfishers, which differs from its nearest ally, Alcedo ispida hispidoides, as follows : The middle of the back and rump, as well as the tips to the feathers of the crown and hindneck, are purplish blue, instead of light or cobalt-blue; the cheek-stripe is very deep blue, not light blue; the feathers behind the eye bluish black; wingcoverts deep blue, with lighter, more purplish blue tips; the patches on the sides of the chest blue-black; the bill is usually higher. Type: $\delta$ ad., No. A. 1244, Rendova, 10. ii. 1904, A. S. Meek coll.

While the series from Rendova and Gizo is easily recognisable from the characters given above, the few skins from Guadalcanar and Treasury Islands, though certainly more blue and very much like the birds from Gizo and Rendova, are somewhat intermediate between $A$. $i$. hispidoides and salomonensis. The forms A. i. bengalensis, floresiana, and hispidoides have been discussed in former volumes of the Journal.

Mr. Meek sent the following specimens :

$1 \delta$ ad., 4 \& ad., 4 q juv., Rendova, February 1904 (Nos. A. 1237, 1241, 1243, $1244,1245,1246,1267,1304,1313)$.

$1 \delta$ ad., 1 \& ad., Gizo, October 1903 (Nos. A. 698, 699).

"Iris dark brown; feet yellowish red (red, burnt red, dull smoky red in some young) ; bill black in adult males, red at base in females."

Judging from a male from the Duke of York Island, collected by Th. Kleinschmidt, the birds from there belong also to A. i. salomonensis, or a closely allied form, but they certainly differ from hispidoides.

\section{Alcyone pusilla richardsi Tristr.}

Alcyone richardsi Tristram, Ibis, 1882. p. 134 pl. 4 (Rendova).

1 f , Gizo, 10. xi. 1903 (No. A. 812).

1 of, 2 q $q$, Choisenl, December 1903, January 1904 (Nos. A. 903, 1090, 1153).

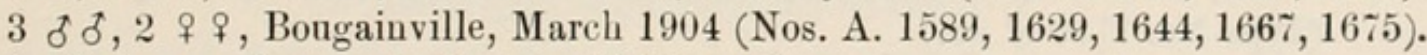

"Iris brown, feet smoky brown, bill black."

This little Alcyone can only be considered as a very closely allied subspecies of A. pusilla. The chief character relied npon by Tristram and Sharpe, i.e. the blue pectoral band, breaks down when a series is compared. While in none of our richardsi it is as complete as in Canon Tristram's tigure, one female from Bougainville (No. A. 1629) has this band as completely absent as in typical pusilla. The only character which appears to be constant is the larger size of the bill. The different shades of blue noted in the original description are found in both subspecies.

\section{Ceyx meeki Rothsch.}

Ceyx meeli Rothschild, Bull. B. O. C. xii. p. 23 (1901: Isabel I.). (Cf. Nov. Zool. 1902. p. 587. pl. xi., fig. 1.)

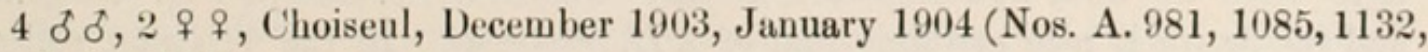
$1133,1134,1149$ ). 
$2 \delta$ ad., 4 q ad., 1 ठ jun., Bougainville, March 1904. (Nos. A. 1159, 1484, $1498,1641,1655,1690,17 \% 4)$.

"Iris dark brown; feet pale yellow (flesh-colour, mottled brown and flesh, smoky brown) ; bill black in both sexes."

39. Ceyx lepida collectoris Rothsch. \& Hart.

Ceyx lepida collectoris R. \& H., Nov. Zool. 1901 p. 376 (Kulambangra and Guadalcanar, errore !

We restrict this name to the birds from the central group!) 1388).

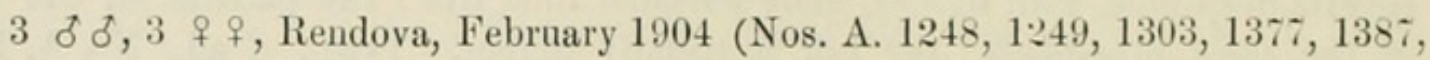

3 ठे ठ, 3 \& $\uparrow$, New Georgia, March 1904 (Nos. A. 1428, 1429, 1450, 1456, 1459, $14 \% 0)$.

"Iris brown, feet and bill red (orange red, chinese red)," in both sexes !

The Guadalcanar form differs from C. $l$. collectoris by the black upper mandible and smaller size! Wings, 60 and $61 \mathrm{~mm}$. only; bill (enlmen), 33 to 36 , but about $3 \mathrm{~mm}$. longer and much thicker in collectoris. We call the Guadalcanar form :

Ceyx lepida nigromaxilla subsp. nov.

(Type + , Guadaleanar, 18. iv. 1901. No. 2925.)

\section{Halcyon bougainvillei Rothsch.}

(Plate X.)

Halcyon bougainvillei Rothschild, Bull. B. O. C. xv. p. 5 (1904: Bougainville).

This remarkable large kingfisher has no near ally, as far as we know at present. The sexes differ conspicuously, the female differing from the male in having the scapulars and interscapular feathers cinnamon-olive-brown with a green tinge, instead of blue. The plate shows the coloration of both sexes. The wing measures 130 , the tail 93 , bill 4 ; to 50 , metatarsus 21 to $22 \mathrm{~mm}$. The female is of the same size.

Mr. Meek sent four specimens.

3 ơ ठै, 1 ค, Bougainville, May 1904 (Nos. 1753, 1762, 1766, 17\%0).

(Type No. 1770 ठे ad.)

41. Halcyon tristrami alberti subsp. nov.

Subspeciei Halcyon tristrami tristrami dictae similis, sed uropygio saturatiore, caerulescentiore, rostro aliquanto breviore distinguenda.

We have compared 30 specimens from the Solomon Islands with the two types, kindly lent to us from the Liverpool Museum, and two specimens in the British Musenm. We find that the former are generally darker above, especially the crown of the head is nearly always darker, the rump much more blue, the tail somewhat blner, the upperside generally darker. The bill is shorter, generally from 3 to $15 \mathrm{~mm}$., sometimes only $2 \mathrm{~mm}$. Type No. 2780, Knlambangra, 21. ii. 1901, ठ, A. S. Meek coll.

II. tristrami, "Ibis," 1880, p. 460, pl. xv., was originally described as donbtfully from Makira Harbour, Solomon Islands. The description, however, does not agree with the form now known from San Christoval, i.e. Sharpe's H. solomonensis, and the figure is also certainly that of a H. tristrami. In the Tristram collection, now in the Liverpool Museum, two specimens from Blanche Bay. New Brittany, 
are marked as the types of 11 . tristrami. Evidently Mr. Layard wrote from memory, and his doubtful locality "Makira Harbour" was an error. Mr. Meek sent the following specimens of $H$. t. alberti:

$2 \delta, 2$ ㅇ ad., 2 б jun., Rendova, February 1904 (Nos. A. 1171, 1189, 1261, $1272,1273,1286)$.

$1 \delta, 1$ \& ad., 1 ठ juш., Gizo, October, November 1903 (Nos. A. 612, 659, 822).

1 of ad., Bougainville, May 1904 (No. A. 1268).

"Iris brown. Bill black, base of under mandible whitish ; feet dark slate."

42. Halcyon sanctus Vig. \& Horsf.

Halcyon sanctus Vig. \& Horsfield, Trans. Limn. Soc. Lond. xv. p. 206 (1826: Australia).

$4 \delta \delta, 1$ f, Rendova, February 1904 (Nos. A. 11\%, 13\%4, 13\%6, 1389, 1390).

$2 \delta$ ठ, 1 \&, New Georgia, March 1904 (Nos. A. 1418, 1423, 1424).

4 ठ์ ठ์, 2 $\uparrow$, Bougainville, April 1904 (Nos. A. 1486, 1503, 1528, 1536, 1540, $1557)$.

\section{Halcyon leucopygius (Verr.).}

Cyanalcyon leucopygius Verreaux, Rev. \& Mag. de Zool. 1858. p. 358 (Solomon Islands).

3 ठ̊ ठै, 3 \& \& , Choiseul, December 1903, January 1904 (Nos. A. 859, 861, 955, $961,1014,1161)$.

$1 \delta, 2 q q$, Bougainville, May 1904 (Nos. A. 1725, 1747, 1776).

"Iris brown ; bill and feet black."

\section{Halcyon saurophaga Gould.}

Haleyon saurophaga Gould, P. Z. S. 1843, p. 103 (New Guinea).

3 ठ̊ ठै, 1 q, Gizo, November 1903 (Nos. A. 781, 788, 810, 837).

2 \& $q$, Choisenl, January 1904 (Nos. A. 1095, 1130).

1 ठे, Bougainville, May 1904 (No. A. 1712).

"Iris brown ; feet dark slate ; bill black, basal half of lower mandible whitish."

45. Centropus albidiventris Rothsch.

"Centropus albidiventris Rothschild, Bull. B. O. C. xiv. p. 59 (March 1904: Gizo).

2 of ad., 1 \& juv., Rendova, February 1904 (Nos. A. 1315, 1326, 1334).

$2 \delta$ ad., Gizo, October, November 1903 (Nos. A. 643, 729).

$\delta \mathrm{ad}$. Head, neck, back, rump and under surface bnff, the lower back, rump and underside more whitish, the feathers of the rump with dull black bases. Wings and tail purplish blue-black. Thighs buff, a blackish patch near the heel-joint. Iris red, bare spot round eye black in the skin, feet slate. Wing $270-80 \mathrm{~mm}$. (not 70 , as said by error in the original description, l.c.), tail abont $340 \mathrm{~mm}$. The young birds resemble those of $C$. milo, but the bars on the rectrices are wider.

\section{Eudynamis orientalis subsp. nov.?}

1 oे, Gizo, 31. x. 1903 (No. A. 696).

2 ठิ ठิ, Choiseul, December 1903 (Nos. A. 886, 1041).

"Iris bright dark red (rose-madder); feet slate-colour; bill greenish slatecolour." 
These birds appear to be, from the colour of their plumage, perfectly adult, but two are in moult. They are like $E$. orientalis rufiventer, but apparently a little smaller. It is not probable that they can be united with $E$. o. rufiventer, since on New Ireland and New Britain we find a form larger than rufiventer. It will be best to await more material from the Solomon Islands, including females !

\section{4\%. Urodynamis taitensis Sparrm.}

Cuculus taitensis Sparrmın, Mus. Carlson. ii. pl. 32 (1787: no locality given, but we may accept Tahiti as the original locality, judging from the specific name).

1 \&, Rendova, 20. ii. 1904 (No. A. 1342).

"Iris light brown ; feet slate ; bill horn-colour."

The specific name is wrongly quoted "taitiensis" in Cait. B. Brit. Mus. xix. p. 314 .

\section{Cuculus saturatus Blyth.}

Cuculus saturatus Blyth, Journ. As. Soc. Bengal, xii. p. 942 (18t3: ex Hodgson MS.; India).

(Cuculus intermedius of the Cat. B. xix.) $1468)$.

$1 \delta, 3+q$, New Georgia, 12, 13, 14. iii. 1904 (Nos. A. 1434, 1440, 1464, 1466 ,

\section{Cacomantis addendus Rothsch. \& Hart.}

Cucomantis addendus Rothschild \& Hartert, Nov. Zool. 1901, p. 185 (Kulambangra). $1467)$.

5) ठ์ ర, 1 \&, New Georgia, March 1904 (Nos. A. 1422, 1437, 1438, 1439, 146\%,

"Iris $\delta$ light brown (reddish brown, dull red), + dull red; feet lemon-yellow ; bill black and horn-colour."

These birds agree with the types from Kulambangra. The female is smaller (wing $112 \mathrm{~mm}$.) than the male, and the rufous-cinuamon colour of the underside reaches npwards to the upper throat, which is only slightly mixed with creamy buff. The males have the chin and upper throat ashy for about one to two centimetres. The wings of the males measure 119 to $122 \mathrm{~mm}$.

\section{Chalcococcyx plagosus (Lath.).}

Cuculus plagosus Latham, Ind. Ord. Suppl. p. xxxi (1801: "New Holland").

1 ơ, Bougainville, 18. iv. 1904 (No. A. 1575).

\section{Rhyticeros plicatus (Forst.).}

Buceros plicatus Forster, Indische Zool.p. 40 (1781 : ex Dampier ; Ceram).

$1 \delta$ ad., Bongainville Island, 2. v. 1904 (No. A. 1716).

"Iris smoky white; feet black; bill of a creamy white bone-colour, base dark red."

\section{Podargus inexpectatus Hart. (? subsp.)}

Podargus inexpectatus Hartert, Bull. B. O. C. xii. p. 24 (Nov. 1901-Isabel Island) ; Nov. Zool. 1902 p. 585 .

3 \& + , Choiseul, 12. xii. 1903 and January 1904 (Nos. A. 929, 1127, 1141).

1 \&, Bougainville, April 1904 (No. A. 1676). 
These specimens agree perfectly with the single female from Isabel (l.c.), except that the wings are smaller, measuring only 198 to $207 \mathrm{~mm}$., while that of the female from Isabel has the wing $220 \mathrm{~mm}$. long. It is therefore possible that these are subspecifically separable, bnt the question cannot be decided until more females from Isabel are available.

\section{Eurostopodus nigripennis Rams.}

Eurostopodus nigripemis Ramsay, Proc. Limn. Soc. N. S. Wales vi. p. 843 (Rubiana).

1 \& Rendova, February 1904 (No. A. 1339).

2 ठ์ ชิ, 2 q + , Gizo, November 1903 (Nos. A. 743, 744, 780, 856).

$1 \delta, 2$ \& . Bougainville, April 1904 (Nos. A. 1649, 1684, 1685).

The sexes are practically alike, the female only having a slightly shorter wing; but some examples of both sexes have not only a large white spot on the inner web of the second, but also a small rusty white one on the inner edge of the first primary, while in others the first two primaries are spotless. Younger individnals have the white patches on the primaries more or less tinged with rusty brown. Probably subspecies of E. albogularis.

\section{Macropteryx mystacea woodfordiana Hart.}

Macropteryx mystacea woodfordiana Hartert, Nov. Zool. 1896. p. 19 (Guadalcanar Isl nd).

1 \& ad., Rendova, 6. ii. 1904 (No. A. 1201).

5 q , New Georgia, March 1904 (Nos. A. 1394, 1395, 1402, 1403, 1419).

2 ठठ ठ, 4 ㅇ ㅇ, Choiseul, December 1903 (Nos. A. 908, 972, 1042, 1043, 1061, 1081).

$2 \delta \delta, 2 q \uparrow$, Bougainville, April and May 1904 (Nos. A. 1703, 1709, 1710, 1\%20).

\section{Collocalia esculenta (L.).}

Hirundo esculenta Linnaeus, Syst. Nat. ed. x. p. 191 (1758: ex Bontius, Ray, Rumphius, Olearius.

"Hab. in China"-errore! I accept Amboina as the loc. typ.).

2 q , 1 ठ juv., 3 doubtful, Choiseul, January 1904 (Nos. 1093, 1096, 1097, 1098, $1115,1116)$.

Clutches of two eggs each were taken on Choiseul on January 10th. The eggs measure $18 \times 11$ and $17.8 \times 11.6 \mathrm{~mm}$.

\section{Pitta anerythra anerythra Rothsch.}

Pitta anerythra Rothschild, Bull. B. O. C. xii. p. 22 (1901: Isabel).

3 б $\delta$, 3 ㅇ , Choiseul, December 1903, January 1904 (Nos. A. 992, 1021, 1102, $1147,1154,1160)$.

These specimens agree perfectly with our series from Isabel. Cf. Noc. Zosl. 1902 , p. 584 , pl. xi. fig. 2.

\section{5\%. Pitta anerythra pallida Rothsch.}

Pitta anerythra Rotbschild, Bull. B. O.C. xv. p. 7 (Oct. 1904-Bougainville).

6 ơ $\delta, 4 q q$, Bougainville, April and May 1904 (Nos. A. 1495, 1523, 1570, $1579,1580,1655,1664,1765,1769,1775)$.

"Iris brown ; feet smoky horn-colour ; bill black." 
This very interesting subspecies differs from $P$. a. anerythra of Isabel and Choisenl in being paler on the underside, and in having the crown of the head much blacker, the chestnut colour being more restricted and sometimes even absent. The amount of chestnut varies, however, much, as sometimes there is as much as in some specimens from Choisenl and Isabel, where, however, all examples have a great amount of chestnut, and mostly much more than those from Bongainville.

An egg was found on Bongainville in May. It is a typical Pitta-egg, being creamy white, marked all over with short lines and scribblings of brownish red and with some underlying greyish mauve spots. It measures $30 \cdot 8$ by $25 \mathrm{~mm}$.

\section{Hirundo tahitica Gm.}

Hirundo tahitica Gmelin, Syst. Nat. i. p. 1016 (1788: ex Latham. hab. Tahiti).

2 ठ์ ठै, 4 f , Bougainville, April and May 1904 (Nos. A. 1542, 1701, 1724, $1737,1738,1752)$.

\section{Rhipidura tricolor (Viell.).}

Muscicapa tricolor Vieillot, Nouv. Dict. d Hist. Nat. xxi. p. 430 (1878-Timor ! errore! We have substituted Amboina as the original locality. Cf. Nov. Zool. 1902. p. 583).

2 ठ์ 6 , 4 ㅇ. Rendova, February 1904 (Nos. A. 1172, 1218, 127\%, 1316, 1340, $1370)$.

2 ठㅎ, 2 \& $q$, Gizo, October and November 1903 (Nos. A. 635, 701, 787, 823).

1 \&, Choiseul, January 1904 (No. A. 1129).

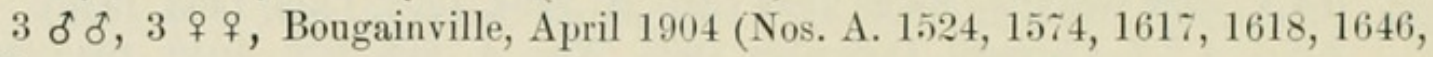
$1695)$.

60. Rhipidura albina Rothsch. \& Hart.

Rhipidura albina Rothschild \& Hartert, Nov. Zool. 1901. p. 183 (Kulambangra).

$2 \delta$ ठ, 1 q ad., Rendova, February 1904 (Nos. A. 1279, 1290, 1300). "Iris dark brown; bill and feet black."

These three specimens agree with the description of our single type from Kulambangra. The type-specimen had some white feathers, irregularly spread over the head and throat ; and onr statement that they were aberrational leucocistic feathers proves to be correct, for our three new specimens do not show them. They have, on the other hand, a narrow white shaft-stripe near the tip of the outer rectrices, distinct in two, barely indicated in the third. The wings of the males measure 88 and 90 , that of the female $85 \mathrm{~mm}$. Otherwise the sexes are alike. The type was probably an exceptionally large specimen, having a wing of $98 \mathrm{~mm}$. This rare species is not a member of the tricolor group, but may possibly be a representative of Rh. cockerelli.

\section{Rhipidura cockerelli (Rams.).}

Sauloprocta cockerelli Ramsay, Proc. Lim. Soc. N. S. Wales iv. p. 81 (1880: Guadalcanar).

$2 \delta$ ठे, 4 q , Choiseul, December 1903 (Nos. A. 876, 883, 919, 956, 973, 1063).

2 ठे ठे, 3 \& \&, Bongainville, April-May 1904 (Nos. A. 1513, 1635, 1636, 1679, 1704).

These specimens agree in everything with those from Guadalcanar and Isabel. The size of the bill is somewhat variable, but not according to localities. 


\section{Rhipidura rubrofrontata Rams.}

Rhipidura rubrofrontata Ramsay, Proc. Linn. Soc. N. S. Wales iv. p. 82 (1880: Guadalcanar).

₹ of $\delta$, 1 \& (albinistic var.), Rendova, February 1904 (Nos. A. 1168, 1204, 1281, $1350,1359,1381,1382,1385)$.

3 ठิ ठี, 3 ๆ ๆ, Gizo, November 1903 (Nos. A. 809, 819, 829, 841, 843, 854).

2 \& $q$, Choiseul, December 1903, January 1904 (Nos. A. 923, 1120).

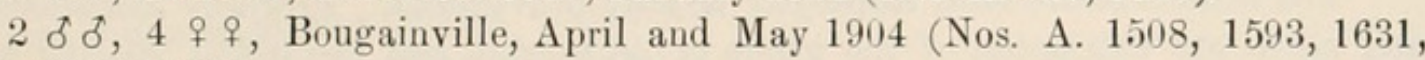
1661, 1732, 1760).

The specimens from Bougainville and Choiseul are apparently slightly smaller, and the cinnamon-red colour of the rump extends perhaps a little more towards the head. Nearly all the specimens are, however, moulting, and it is, therefore, difficult to say whether these apparent differences are of much importance. Moreover, we have no specimens from the original locality (Guadalcanar) to compare.

No. A. 1204 from Rendova is a somewhat peculiar aberration. The upper surface is white, with the exception of the cinnamon-red forehead, a few brown feathers on the crown and nape, some few of the upper wing-coverts, and a few of the upper tail-coverts. The wings are partly brown, partly white, two of the primaries on each side and the majority of the secondaries being of the latter colour. The tail is of the normal colour. The under surface is pure white, with the exception of two brown feathers on the throat and the pale cinnamon under tail-coverts. The specimen is not an albino, the iris being brown and not pink, the feet brown, the bill brownish black.

\section{Myiagra ferrocyanea ferrocyanea Rams.}

Myiagra ferrocyanea Ramsay, Proc. Linn. Soc. N. S. Wales iv. p. 80 (1879-Guadalcanar).

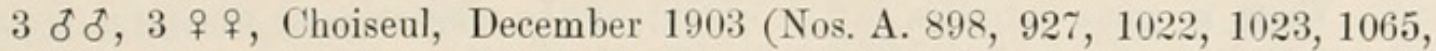
1079).

2 ठ์ ठ์, $2+q$, Bougainville, April 1904 (Nos. A. 1522, 1537, 1630, 1678).

ठิ?. "Iris (dark) brown ; feet black (very dark slate) ; bill chalky blue."

The male has the throat black, upper wing- and tail-coverts purplish blne. The female has the crown and hind-neck grey, back rusty brown, central rectrices cinnamon-brown, the rest bright cinnamon, the quills edged with bright cinnamon. Underside white, the abdomen with a light rusty-bnff tinge.

We have now specimens from Guadalcanar, Florida, Isabel, Treasury, Choiseul, Bougainville, and Munia in the Shortland group.

\section{Myiagra ferrocyanea feminina Rothsch. \& Hart.}

Myiagra feminina Rothsch. \& Hartert, Nov. Zool. 1901. p. 183 (Kulambangra). 1367).

4 ठิ ठ, 2 \& + , Rendova, February 1904 (Nos. A. 116\%, 1310, 1338, 1347, 1360,

$3 \delta$ ad., 1 o juv., 5 \& + , Gizo, October and November 1903 (Nos. A. 629, 632, $656,745,747,753,779,786,832)$.

The male differs from that of $M . f$. ferrocyanea in being uniform blue-black with a steely gloss, but without any purplish tinge. The female has the head above bluish grey, the rest of the upper surface grey with an ashy-brownish tinge, the under surface white from chin to tail.

ठ q. "Iris brown ; feet (dark) slate ; bill chalky blue." 
65. Monarcha kulambangrae meeki subsp. nov

Differs from $Y . k$. lulambangrae in having less white in the tail. The outer rectrices, which are white for $23(q)$ to $29(\delta) \mathrm{mm}$. in M. k. kulambangrae, are white only for 11 and $18(\uparrow)$ to 17 and $215(\delta) \mathrm{mm}$. in $M$. k. meeki. Otherwise there is no appreciable difference.

The nomenclature here employed is only provisional. Probably kulambangrae and meeki are subspecies of the group of $M$. brodiei, and the oldest specific name of this group of subspecies may not even be brodiei. We hope to discuss these flycatchers later.

(Type of M. k. meeki: o ad., Rendova, 23. ii. 1904. No. A. 1355, A. S. Meek coll.)

The differences of kulambangrae and brodiei are fully stated in the original description (Nov. Zool. 1901. p. 183).

Mr. Meek sent the following specimens from Rendova :

3 ठे $\delta$, 2 q ad., 1 q juv., Rendova, February 1904 (Nos. A. 1202, 1210, 1282, 1289, 1355, 1356, 1369).

"Iris brown ; feet bluish slate ; bill chalky blue."

\section{Monarcha brodiei Rams.}

Monarcha brodiei Ramsay, Proc, Lim. Soc. N. S. Wales iv. p. 80 (1879: Guadalcanar).

$4 \delta$ ad., 1 o juv., 2 \& juv., Choiseul, December 1903, January 1904 (Nos. A. $880,942,1062,1099,1101,1106,1131)$.

$2 \delta$ ad., $2 q$ ad., $1 \delta$ juv., 1 $q$ juv., Bougainville, April and May 1904 (Nos. A. $1488,1497,1512,1543,1693,1746)$.

There is some variation in the extent of the white tips to the outer rectrices. Generally this is smallest in the specimens from Guadalcanar, and those from Isabel are indistinguishable from the latter; while specimens from Choisenl are inclined to have more white, and most of those from Bongainville have distinctly more white on the outer rectrices. This difference is, however, not nearly so constant and marked as it is in kulambangrae and meeki, and we are, therefore, not inclined to separate the forms from the northern islands without further evidence.

The form we called M. brodiei floridana (Nov. Zool. 1901. p. 183), which has white edges to the primary coverts and some of the inner secondaries, is evidently quite distinct, and hitherto only known to us from our two males from Florida Island.

\section{Monarcha castaneiventris castaneiventris Verr.}

Monarcha castaneiventris Verreaux, Rev. \& Mag. de Zool. 1858. p. 304 ("Samoa"-errore! Doubtless the type came from the Solomon Islands).

$3 \delta$ ad., 1 o juv., 2 \& juv., Choisenl, December 1903, January 1904 (Nos. A. $873,962,1013,1026,1057,1136)$.

"Iris ( $\delta$ ad.) brown; feet and bill dark slate-colour."

One of the young females has the upper mandible abnormally lengthened and hooked. 


\section{Monarcha castaneiventris erythrosticta (Sharpe).}

Pomarea erythrosticta Sharpe, P. Z. S. 1888. p. 185 (Fauro).

Pomarea ribbei Hartert, Nov. Zool. 1895. p. 485 (Munia).

Two of onr specimens, "Male?" No. A. 1694, and "Female" No. A. 1476, have a pale cinnamon patch in front of the eye, like Sharpe's type of erytlerosticta, the others a white one, like Hartert's type of ribbei. We have therefore no doubt that the two supposed species belong to one and the same form. They are evidently a northern representative of castaneiventris.

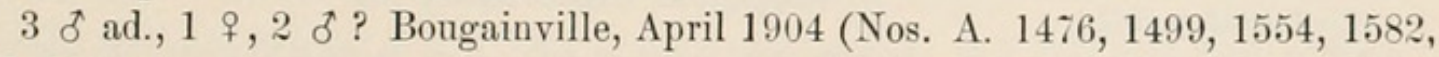
1692, 1694).

Nos. A. 1499 and A. 1554, marked as males, have a much darker and less bright abdomen. In the latter specimen the bill is abnormally crossed, like the bill of a Loxia.

"Iris brown ; feet slate ; bill slate-blue with black tip."

\section{Monarcha richardsii (Rams.)}

Piezorhynchus Richardsii Ramsay, Proc. Linn. Soc. N. S. Wales vi. p. 177 (1882 : “Ugi').

Piezorhynchus florenciae Sharpe, Ibis 1890. p. 206 (Rubiana=New Georgia).

3 o ad., 1 o juv.? (marked $q$ ), 1 q ad., 1 juv., Rendova, February 1904 (Nos. A. 1163, 1165, 11\%0, 1239, 1278, 1305).

$4 \delta$ ad., $2 \delta$ jun.? (marked $q$ ), 1 very young male, 1 juv., Gizo, October and November 1903 (Nos. A. 604, 616, 622, 634, 650, 738, :84, 839).

The adult males agree perfectly with Dr. Ramsay's description, though it would be desirable to compare a series from Ugi, where the type has been said to come from. What we take to be adult females are as follows: Whole upper surface slaty grey, wings and tail darker, throat and chest paler, lower breast, abdomen and nnder tail bright chestnut. These birds are the females of Sharpe's florenciae. The immatnre females have the throat and chest washed with light chestnut. The immature males are like the female, but head, throat and ear-coverts are more or less blackish slate, a wide line behind the eyes and a patch on the sides of the neck, and a partial ring around the eyes white. These immature males are the males of Sharpe's florenciae. One of our three young males from Gizo (No. A. 738) has the throat white, but this is clearly albinistic.

"Iris dark brown ; feet slate-colour ; bill chalky blue."

\section{Monarcha inornata (Garnot).}

Muscicapa inornata Garnot, Voy. "Coquille," Zool. Atl. pl, xvi. fig. 2 (1826), i. 2 p. 591 (1828: New Guinea).

1 ơ 1 \& juv., Choiseul, 30. xii. 1903 (Nos. A. 1074, 1075).

A series of adult specimens from the Solomon Islands alone can prove whether these examples are typical inornata, or belong to a distinct race.

\section{Graucalus welchmani subsp.?}

Graucalus welchmani Tristram, 1bis 1892. p. 294 (Bugotu=Isabel).

3 ơ ad., Bongainville, April 1904 (Nos. A. 1531, 1556, 1602).

"Iris dark brown ; bill and feet black."

These three males differ conspicnonsly from our two males from Kulambangra 
in having the black of the throat extending to the chest, and by shorter and stouter bills. We suspect that these birds are the males of true welchmani, the type of which is a female in spite of having been described as a male, and that the Kulambangra form will have to be separated. Males from Isabel only can finally settle the question.

\section{Graucalus hypoleucus elegans Rams.}

[Graucalus hypoleucus Gould, P. Z. S. 1848. p. 38 (Port Essington, Australia).]

Graucalus elegans Ramsay, Proc. Limm. Soc. N. S. Wales vii. p. 22 (1882: Guadalcanar). (Cf. Nox. Zool. 1902. p. 582.)

3 o ad., 1 q, New Georgia, March 1904 (Nos. A. 1408, 1412, 1415, 1442).

1 f, Gizo, 29. x. 1903 (No. A. 670).

3 ơ ठै, Choiseul, December 1903 (Nos. A. 909, 979, 1050).

3 ठठ $\delta$, 3 \& \& , Bongainville, April and May 1904 (Nos. A. 1525, 1638, 1702, $1 \% 06,1739,1 \% 51)$.

"Iris brown; bill and feet black."

\section{Graucalus pusillus ombriosus subsp. nov.}

This form is the one inhabiting the western central group of the Solomon Islands, namely New Georgia, Rendova, Gizo, and Kulambangra. It differs from G. p. pusillus by being more sooty on the upper surface, not so light grey.

Type $\delta$ ad., Gizo, No. A. 695. We have the following specimens :-

$1 \delta$, Rubiaua (=New Georgia), collected in 1894 by Captains, Webster and Cotton (from spirits).

$2 \delta$ ad., 2 o jun., 2 \% + , Kulambangra, February and March 1901, collected by A. S. Meek (Nos. 2775, 2789, 2794, 2798, 2821, 2822). These are the birds quoted as G. pusillus, Nov. Zool. 1901. p. 180.

2 o ad., 2 o imm., 2 q $q$, Rendova, March 1904 (Nos. A. 1190, 1263, 1264, $1280,1317,1349)$.

3 ठิ ठิ, 2 ๆ ๆ, Gizo, October 1903 (Nos. A. 605, 607, 669, 6r7, 695).

"Iris bright yellow ; bill and feet black."

\section{Graucalus pusillus nigrifrons Tristr.}

[Graucalus pusillus Ramsay, Proc. Linn. Soc. N. S. Wales iv. p. 71 (1879: Guadalcanar).]

Graucalus nigrifrons Tristram, Ibis, 1892. p. 294 (Bugotu=Isabel). Cf. Nov. Zool. 1902. p. 582, where, however, the differences between the two forms have been accidentally inverted. In fact, nigrifrons is barely separable, differing in no other way from $G$. p. pusillus, than being slightly paler grey.

1 o, 1 \% , Choiseul, 22. xii. 1903, 7. i. 1904 (Nos. A. 1005, 1112).

$2 \delta$ ad., 1 o jun., 1 \& , Bongainville, April 1904 (Nos. 1604, 1622, 1650, 1652).

"Iris bright yellow ; bill and feet black."

75. Edoliisoma erythropygium saturatius Rothsch. \& Hart.

Edoliisoma erythropygium saturatius Rothschild and Hartert, Nov. Zool. 1902. p. 582 (Isabel [type], Kulambangra and Shortland Islands).

1 ठ imm. 1 ठ juv., 4 q $q$, Rendova, February 1904 (Nos. A. 1183, 1291, 1293, $1309,1320,1332)$.

$4 \delta$ ad., 1 ठ juv., 1 \&, Gizo, October and November 1903 (Nos. A. 671, 678, $690,712,714,758)$. 


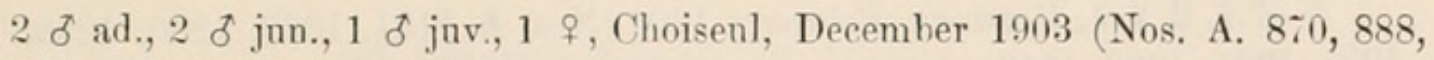
$893,945,982,1004)$.

$4 \delta$ ad., 1 q ad., $1+$ juv., Bongainville, April and May 1904 (Nos. A. 1514, $1566,1594,1625,1681,1705)$.

"Iris brown ; feet dark slate ; bill black."

Fully adult males have the throat more or less black, which is not the case in E. e. erythropygium. The size of the bill is somewhat variable.

\section{Edoliisoma holopolius (Sharpe).}

Grancalus holopolius Sharpe, P. Z. S.1888. p. 184 (Guadalcanar). (Cf. Nor. Zool. 1901. p. 374.)

$3 \delta$ ad., Choisenl, December 1903 (Nos. A. 937, 968, 1017).

$4 \delta$ ad., 3 \& ad., Bongainville, April and May 1904 (Nos. A. 1481, 1520, 1640, $1648,168: 2,1722,1723)$.

"Iris brown ; bill and feet black."

7\%. Geocichla papuensis Seeb. (? subsp. nov.)

Geocichla papuensis Seebohm, Cat. B. Brit. Mus.v. p. 158, pl. ix. (1881 : “S.E. New Guinea ").

1 q, immat., Choisenl, 13. i. 1904 (No. A. 1148).

"Iris dark brown; feet light horn-colour; bill blackish, base of lower mandible pale."

This single specimen is immature and moulting, and therefore we do not venture to separate it from $G$. papuensis, though the bill is $2 \mathrm{~mm}$. longer than in our two specimens of the latter, and the rump is apparently darker.

\section{Pachycephala astrolabi $\mathrm{Bp}$.}

Pachycephala astrolabi Bonaparte, Consp. Av. i. p 329 (1850 : ex Hombr. \& Jacq., Voy. Pôle Sud, pl. v. fig. 3, hab. "San Jorge").

5 ठ̊ ठ, 1 \&, Rendova, February and March 1904 (Nos. A. 1193, 1213, 1232, $1233,1262,1471)$.

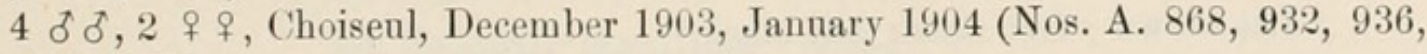
$947,969,108 \%)$.

3 o ad., 2 o juv., 2 웅, Bougainville, March 1904 (Nos. A. 1479, 1500, 1521, $1544,1545,1553,1564)$.

In addition to the variations of females and immature birds described in Nov. Zool. 1901, p. 375, we must mention the following two females :-

“ \&," No. A. 1479, Bougainville: Throat, sides of neck, breast and sides of abdomen cinnamon-rufous, forehead, and outer aspect of wings ochraceous-rufous, centre of abdomen and vent buff.

“,$+ " N o$. A. 936, Choiseul : Upper surface bright olive, whole under surface golden yellow; wings fuscous with rufous edges.

\section{Zosterops rendovae Tristr.}

Zusterops rendorae Tristram, Ilis, 1882. p. 135 (Rendova).

Differs from Z. kulambangrae (Nov. Zool. 1901, p. 180) in having no white orbital ring and no such black loral spot.

Dr. Finsch (Tierreich Lief. xv. p. 26) nnites with Z. rendovae Dr. Ramsay's Z. ugiensis! Seeing that such closely neighbouring islands as Kalambangra and Rendova bave different forms, one is not justified in accepting such a view, 


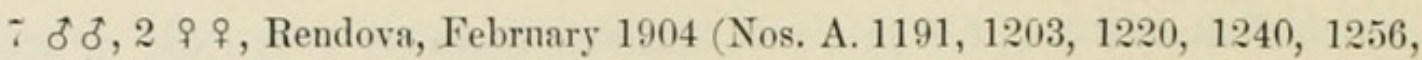
$1257,1295,1296,1312)$.

"Iris dull red (hazel, bright chocolate) ; feet straw-yellow ; bill black."

\section{Zosterops luteirostris Hart.}

Zosterops luteirostris Hartert, Bull. B.O.C., March 1904 (Gizo).

5 ठ̊ ठै, 5 \& $q$, Gizo, October and November 1903 (Nos. A. 606, 631, 633, 724, $748,761,795,803,840,855)$.

"Iris dark red (plum-red); feet straw-yellow ; bill dark straw-yellow)."

81. Zosterops metcalfei Tristr.

Zosterops metcalfei Tristram, Ibis, 1894, p. 29, pl. iii. (Bugotu = Isabel). (Cf. Nov. Zool., 1902, p. 581 .)

$2 \delta$ ठ, 3 $q$ ? , Choisenl, December 1903 (Nos. A. 864, 935, 952, 985, 1030).

3 ठे ठे, 3 ๆ ๆ , Bongainville, April 1904 (Nos. A. 1494, 1596, 1614, 1615, 1628, $165 \%)$.

"Iris chocolate-brown ; feet slate ; bill black and horn-colonr."

\section{Myzomela eichhorni Rothsch \& Hart.}

Myzomela eichhorni Rothschild \& Hartert, Nov. Zool., 1901, p. 181 (Kulambangra); Nov. Zool. 1902. pl. VII. figs. $1,2$.

We have now received a number of adult females. They are much smaller than the males (wing about $62 \mathrm{~mm}$.), the crown is much lighter, not blackish, the rnmp olive with a rnsty tinge, but not red. The young resemble the females, but the males are larger, and the red on the rump appears at the first monlt.

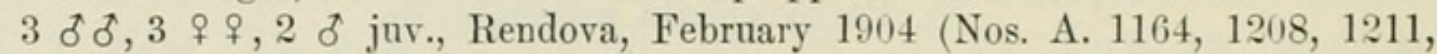
121 \% $1221,1229,1242,1292)$.

4 ठิ ठิ, New Georgia, March 1904 (Nos. A. 1407, 1453, 1463, 1465).

$4 \delta$ ad., 5 \& ad., 1 o juv., Gizo, Angust 1901, October and November 1903 (Nos. 3539, 3540, A. 702, 708, 722, 752, 763, 799, 800, 834).

"Iris brown ; feet slate; bill black."

The birds from Gizo are rather smaller than those from Kulambangra, Rendova, and New Georgia.

\section{Myzomela lafargei Jacq. \& Puch.}

Myzomela lafargei Jacq. \& Puch., Voy. Póle Sud. Zool., Ois., p. 98 (1853-Solomon Islands).

The female differs considerably from the male. It is above very dark olive, not black; the crown like the back, not red; the throat olive-brown, instead of black; breast and abdomen duller.

4 ठ̊ ad., 1 \&, 3 ơ juv., Choiseul, December 1903, January 1904 (Nos. A. 904, $921,988,1051,1054,1117,1143,1145)$.

$3 \delta$ ad., 2 $\uparrow, 2$ o juv., Bongainville, April and May 1904 (Nos. A. 1496, $1511,1584,1585,1586,158 \%, 1713)$.

\section{Dicaeum aeneum Jacq. \& Puch.}

Dicaeum aeneum, Jacq. et Pucheran, Voy. Pôle Sud, Zool., Ois., p. 97 (1583: "San Jorge").

4 ठో ठึ, 3 \& $\uparrow$, Choisenl, December 1903, January 1904 (Nos. A. 890, 894, 896, $897,1007,1033,1144)$.

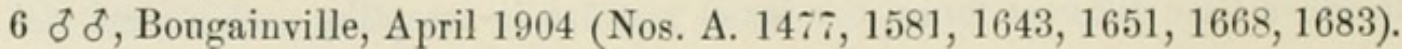




\section{Cinnyris frenata (S. Miill.).}

Nectarinia frenata S. Miiller, Land-en Volkenkunde, p. 173 ("Door ons an de westkust van NieuwGuinea ontdekt").

In Nov. Zool. 1903, p. 213, we came to the conclusion that the form from New Ireland and Solomon Islands could not be separated from the typical New Guinea form. We are, however, not quite cèrtain if the Moluccan form, which is less bright yellow below and not so bright above, might not be separable, and there is also no doubt that all our Solomon Islands are extremely bright in colour. Perhaps the examination of a series of very fresh skins might after all justify Dr. Heinroth's " $C$. frenata flava," but more likely necessitate the creation of another Moluccan race.

Mr. Meek sent the following fresh series :

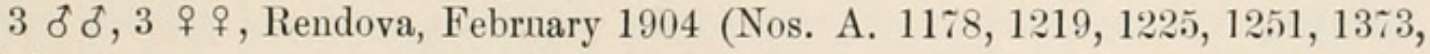
$1373 \mathrm{~A})$. 765).

5 ठิ ठे, 1 f, Gizo, October, November 1903 (Nos. A. 691, 709, 726, 741, 754,

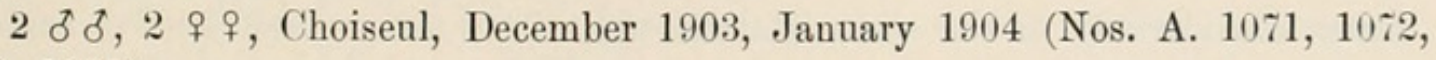
$10-3,1121)$.

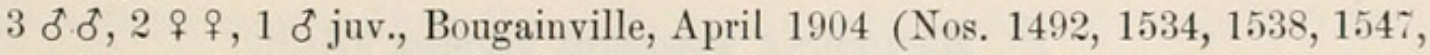
$1558,1561)$.

\section{Calornis cantoroides Gray.}

? Lamprotornis cantor S. Müller, Verh. Nat. Gesch. Nederl. orerg. bez., Land-en Vollienlinude, p. 22 (1844-descr. nulla, errore, non Turdus cautor Gm. !).

Calornis cantoroides Gray, P.Z.S. 1861, pp. 431, 436 (Mysol).

3 ठे ठ, 1 \&, Gizo, November 1903 (Nos. A. 710, 742, 782, 783).

4 ठठ ठ์, 1 \&, Choisenl, December 1903 (Nos. A. 902, 991, 1068, 1069, 1080).

2 \& juv., Bougainville, April 1904 (Nos. A. 15.52, 1578).

\section{Calornis metallica (Temm.).}

Lamprotornis metallica Temminck, Pl. Cal. 266 (1824: "Timor et Celebes," errore! We have to accept Amboina as the typ. loc. Cf. Salvad., Orn. Pap. ii. p. 447).

2 ơ juv., 3 \& $q$, Rendora, February 1904 (Nos. A. 11\%3, 11\%6, 1285, 1299, $1322)$.

1 ơ, Gizo, November 1903 (No. A. 727).

1 ơ, 1 f, Choiseul, December 1903 (Nos. A. 900, 976).

\section{Calornis fulvipennis (Jacq. \& Pnch.).}

Lamprotornis fulvipennis Jacq. \& Pucheran, Voy. Pôle Sud, Zool. iii. p. 81 (1853-Isabel, Solomons). Lamprotornis grandis Salvadori, nom. emend. for $L$. fulvipennis.

Calornis maxima Tristram, Ibis, 1895, p. 375 (Isabel !). (Cf. Nov. Zool. 1902, p. 584.) 1319).

5 ơ ठ, 1 \& , Rendova, February 1904 (Nos. A. 1182, 1184, 1206, 1215, 1318,

1 ठ, 1 ๆ, Gizo, October 1903 (Nos. A. 661, 662).

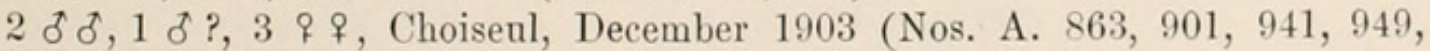
$963,99 \tau)$.

3 of ad., 3 ad., 1 o juv., Bongainville, April 1904 (Nos. A. 1504, 1535), 1561, $1600,1632,1658,1680)$. 
The young bird is considerably smaller, the feathers of the throat, head and neck are very elongated and attennated, those of the rump and abdomen are shorter and more blackish, and the quills are darker brown, than in adnlt birds.

"Iris brown or dark red ; bill and feet black."

\section{Mino kreffti (Scl.).}

Gracula lieffti Sclater, P. Z. S. 1869. p. 120, pl. ix. ("Ins. Salomonenses").

4 ठठ ठ, 2 \& + , Rendova, February 1904 (Nos. A. 1194, 1195, 1222, 1236, 1284, 1298).

2 ठํ ठํ, 4 \& + , Gizo, October 1903 (Nos. A. 646, 647, 693, 694, 697).

3 б ठठ, 3 q $q$, Choisenl. December 1903 (Nos. A. 877, 878, 995, 996, 1016, 1038).

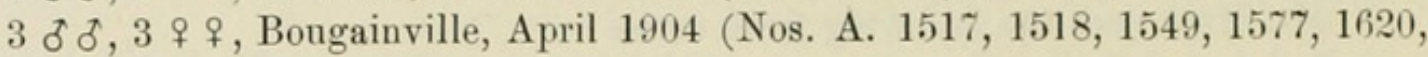
$1621)$.

"Iris bright yellow, feet and bill orange (cadmium)."

The specimens from Bongainville are generally largest, those from Gizo smallest. We are, however, not ready to separate any subspecies, becanse the size varies considerably in the same islands.

\section{Macrocorax woodfordi vegetus Tristr.}

[.Hacrocorax woodfordi Grant, P. Z. S. 1887, p. 332 ; Guadalcanar.]

Macrocorax vegetus Tristram, Ibis, 1894, p. 30 (Bugotu-Isabel). Cf. Nov. Zool. 1902, pp. 583, 584).

1 б, 2 q $q$, Choiseul, December 1903 (Nos. A. 861, 889, 958).

91. Corvus meeki Rothsch.

Corcus meeki Rothschild, Bull. B. O. Club, November 1904 (Bougainville).

$2 \delta$ ठठ ad., Bongainville, May 1900 (Nos. A. 1719, 1748).

"Iris brown, bill and feet black."

Only these two males of this remarkable new Raven were obtained by Mr. Meek. 


\section{$2 \mathrm{BHL}$ Biodiversity Heritage Library}

Rothschild, Lionel Walter Rothschild and Hartert, Ernst. 1905. "Further contributions to our knowledge of the Ornis of the Solomon Islands." Novitates zoologicae : a journal of zoology in connection with the Tring Museum 12, 243-268. https://doi.org/10.5962/bhl.part.24272.

View This Item Online: https://www.biodiversitylibrary.org/item/23228

DOI: https://doi.org/10.5962/bhl.part.24272

Permalink: https://www.biodiversitylibrary.org/partpdf/24272

\section{Holding Institution}

Natural History Museum Library, London

\section{Sponsored by}

Natural History Museum Library, London

\section{Copyright \& Reuse}

Copyright Status: Public domain. The BHL considers that this work is no longer under copyright protection.

This document was created from content at the Biodiversity Heritage Library, the world's largest open access digital library for biodiversity literature and archives. Visit BHL at https://www.biodiversitylibrary.org. 